\title{
Beach Utilization as Tourist Attraction and Ritual in Badung Regency
}

\author{
$1^{\text {st }} \mathrm{Ni}$ Gst Nym Suci Murni \\ Tourism Departmment \\ State Polytechnic of Bali \\ Badung Indonesia \\ gustinymsucimurni@pnb.ac.id
}

\author{
$2^{\text {nd }}$ Made Ruki \\ Tourism Departmment \\ State Polytechnic of Bali \\ Badung Indonesia
}

\author{
$3^{\text {rd }}$ Dewa Made Suria Anatara \\ Tourism Departmment \\ State Polytechnic of Bali \\ Badung Indonesia \\ dwsuria@pnb.ac.id
}

\begin{abstract}
Sustainable tourism has always been a reference in the development of tourism around the world, the awareness of tourism industry actors, local community, and visitors, in supporting tourism development increasingly heavily heard as a discourse to improve the welfare of the community. This research uses the approach of cultural studies and tourism. The specific objectives of this research (1) to know the use of the beach as a tourist attraction and ritual, (2) to determine the impact of beach use on sustainable tourism, (3) create a model of beach use for sustainable tourism. The research method is qualitative interpretive method in accordance with social research. Data collection is obtained through observation and in-depth interviews with Head of Kuta Village (Bendesa Adat) and Head of sub-vilage (Klian adat) that are consisting of 13 subvillage (banjar) that support Kuta Tourism area. For Nusa Dua area, the interview is conducted on three Bendesa Adat (Bualu, Kampial, Peminge) and 12 heads of subvilages. The research results show that (1) the beach utilization in Nusa Dua and Kuta tourist areas is almost the same as tourist attractions and rituals, but some tourism activities are diferent, (2) the impact of utilization of beach viewing of the two regions can be seen from economic, social/cultural, and environmental impacts, (3) Beach utilization models to support sustainable tourism should involve the government of Badung Regency, Desa Adat, and stakeholders to determine the utilization of zonation.
\end{abstract}

Keywords-beach utilization, tourist attraction, ritual, sustainable tourism

\section{INTRODUCTION}

Sustainable tourism is a central issue in the world of tourism in the management of tourism assets and businesses so that it can give benefit economically, socially/culturally and environmentally [1], [2]. Tourism that is influenced by globalization is one of the important sectors in Indonesia, even almost all over the world because it can provide a multiplier effect on people's income, absorb employment, and increase foreign exchange income for the country. Apart from its positive impact, especially on the economy, tourism also has a negative impact on social/cultural and the environment [3], [4], [5].

Beach utilization in Badung Regency in this case takes two beach samples in both tourism areas that are already wellknown internationally, Nusa Dua beach (Samuh and Mangiat) and Kuta beach which is an iconic in Kuta tourism area. The selection of the two beaches is based on the different types of areas, where Kuta is an integrated development area, while Nusa Dua area with enclave development [6] Until now Kuta beach is very famous because some tourist attractions can be enjoyed and seen by domestic and international tourists, like seeing the sunset in the afternoon, the big and long waves for surfing, long white sandy beaches with shady trees as sunbathing and massage activities, tattoos, beach games, swimming, fishing. and there are many other attractions that can be done on the beach. Likewise, Nusa Dua beach is also very interesting, such as the Mengiat beach, Samuh beach, which nearby are some five star hotels. Beside that, around the beach there are still many activities that can be enjoyed by tourists, such as shopping, hunting culinary and also watching religious ritual activities carried out by local community around Kuta and Nusa Dua and Badung community in general.

Besides being used by tourists, Kuta beach and Nusa Dua beach as a water source of life are also used by locals and the surrounding community for religious rituals such as melasti activities (purification of upakara dewa yadnya) when approaching Nyepi day and the great temple ceremony, nangluk merana (bhuta yadnya), ngangkid and mendak (manusa yadnya), mendak and nganyut (pitra yadnya) as well as the need for holy water for the Hindu priest ceremony (resi yadnya). Utilization of Kuta and Nusa Dua beaches is carried out spontaneously and synergizes between the use of tourists on the beach activities, and by the local community in terms of religious ritual activities. Such activities have been going on for a long time, along with the typology of developing tourism areas. Regardless of the type of area, local communities must remain able to be involved economically, socially/culturally and environmentally [7], as described in [8], whatever business style is carried out in coastal utilization, must still save environmental, social, economic assets. The government as one of the stakeholders in three folding (politics, economics, culture) [9], or in the world of tourism as (government, investors, local communities), in this case the support of local government is the key to maintaining sustainable use of marine resources and ensuring local economic sustainability that depending on available resources [10], [11]. 
However, there are problems in using public space for religious rituals. Often hotels/restaurants near the beach claim as if the beach is part of its property. Along with the continuous use of the beach by tourists and the use of the beach as a ritual activity by the surrounding community, it is necessary to find and create strategies that can be used as a model for the utilization of sustainable tourism economically, socially, culturally, and environmentally.

\section{RESEARCH METHOD}

This study uses qualitative-intrepretive analysis [12], approached with cultural studies and sustainable tourism studies. Data was collected through observations in Nusa Dua and Kuta tourism areas. The research instrument is the researcher itself, equipped with a voice recorder to conduct indepth interviews with respondents. The data collection techniques are through observation, documentation, and indepth interview with Head of Kuta Traditional Village (Bendesa Adat) and 13 Head of Kuta Traditional sub villages (Klian Adat). While for Nusa Dua, data and information gained by interviewing Head of Traditional Village (Bendesa Adat) of Bualu, Kampial, and Peminge, as well as 8 Klian Adat of Bualu, and 4 of Kampial and Peminge. Beside that, for verifying the information, other informans (head of peguyuban, head of koperasi, massager, fishermen are also interviewed. While the analysis technique is in accordance with the procedures of qualitative analysis as stated in [13], data reduction, presentation, conclusion and verification.

\section{RESULTS AND DISCUSSION}

A. Utilization of Beach as Tourist Attractions and Rituals in Kuta and Nusa Dua Beach Areas

The use of the beach as a tourist and ritual attraction in the Kuta and Nusa Dua areas has almost the same tourism attraction and ritual activities, but the use of beach as a tourism has several differences. In the following description will be explained the similarities and differences in utilization of the two beaches.

\section{- Beach in the Nusa Dua Tourism Area}

Nusa Dua Beach especially the Samuh and Mengiat beaches are used by tourists and local community. As a tourist attraction more tourists use it than the local community, while the use of the ritual as a whole is used by the local community. As a tourist attraction, the two beaches are used for bathing, swimming because the waves are very calm, fishing, snorkeling at the Bali Under Water Cultural Park (artificial reefs located on this beach). Besides that, tourists can ride a bicycle to Nusa Darma Island, see sunrising, sunbathing, massage, and water sports. The ritual activities carried out by the local community such as melasti before the feast of nyepi, nganyut, melukat, ngangkid, mesuci, and others according to the needs of the local community.

- $\quad$ Beach in the Kuta Tourism Area
The use of Kuta beach is not much different from Nusa Dua beach in terms of tourist attractions and rituals. The difference is the use of Kuta Beach has 5 business zones and for the ritual there is also an agreement in custom, that the beach used ritual activities such as melasti, is done at Kuta beach (the main gate) in front of the Hard Rock Hotel to the north until Jalan Melasti. For ceremony of nganyut, melukat, nangluk merana, mesucian, and others is determined on the beach which is located near Pura Segara or the people of Kuta call it a beach of worship or near setra (grave) While for business zones it is regulated by the Traditional Village of Kuta.

\section{B. Impact of Beach Use as Tourism Activities and Rituals on Sustainable Tourism}

The impact of coastal use can be seen from the socio-cultural, economic and environmental aspects.

\section{- Social / Cultural Factors}

Socially/culturally the use of the beach for both tourism and ritual activities in Badung Regency, has a positive impact on the local community because it can increase the creativity of the locals, the interaction between tourists and locals, improve the quality of yadnya (holy sacrifation), maintain the function of the beach as a ritual, can control and cooperate with the hotel in religious ritual activities carried out on the beach. The level of crime is also reduced due to increasing public awareness of the importance of tourism in their respective area. According to figures from the Bualu Village community, it was said that in order to avoid conflicts between hotel owners and the community who also use the beach as appropriate recreation and rituals, it was agreed to form community groups (peguyuban) in order to make zonation of locations and business zones operating at beaches zones in front of the hotel. The name of the peguyuban also uses the name of the hotel so that it is easy to remember it. However, socially/culturally it has a negative impact on the history of the beach, because over time the community will get used to name it, and fearing that the name of the beach will gradually disappear.

Whereas the social/cultural impact for the use of Kuta beach, as revealed by Head of Kuta Village (Bendesa Adat) Mr. Wayan Suwarsa, that the management of Kuta beach, has been carried out independently by Desa Adat, especially determination of tourist zones and business zones. So socially and culturally there is no problem between the two uses. Socially, local people can do ritual activities on Kuta beach, even though there are minor disturbances, such as tourists roaming around during the ceremony. Like during the melasti ceremony on Kuta beach, as said by Ketut Astawa, community leaders, even though they had been given a restrictive flag, between melasti ceremonies and visiting tourists, there were still a such problems. Other problem that often happen is in naming beaches, some people who call the name of the beach using the name of the hotel, but only a reminder, for example Hard Rock beach in front of Hard Rock Hotel, Mercure beach, Centro beach, sea view beach, pertamina cottage beach, and others. But for the Kuta beach name, is impossible to be 
forgotten because it is an icon of the area that has been famous over the world since long time ago.

\section{- $\quad$ Economic Impact}

The most obvious economic impact of beach ulilization as tourist attraction on the Nusa Dua beach is that local community can directly enjoy the results of tourism activities such as participating in the management of Yasa Segara (Koperasi) in Mengiat Beach, where the business units under its control which are managed in groups by local community. Water sports business, long chair rental for tourists sunbathing, massage, bicycle rental, fishing equipment rental, snorkeling, diving, restaurants, souvenir traders, and others. While for Samuh beach, the name of the cooperative unit (Koperasi) is Merta Segara, and the number of peguyuban is more than in Mengiat beach, and each peguyuban has their chairman. As for Kuta beach, the business zone has been established by Desa Adat, as described in Astawa [14], that the business zone for Kuta Traditional Village in connection with tourism activities including the use of Kuta beach is divided into 5 business zones namely Kuta beach business zone, art market, night market, immigrant population, and Kuta LPD (microfinance). Indirectly, almost all business zones in Desa Adat of Kuta relate to the beach because all of the existing business comes from the attractiveness of Kuta beach which is already famous throughout the world.

\section{- Environmental Impact}

In terms of the environment there are two impacts that occur on the use of the beach in Nusa Dua, namely the positive and negative impacts. The positive impact that can be seen and felt as stated by Mr. Wayan Solo (Head of Benoa Village), that Nusa beach is very different compared from previous time, that the beach environment around the Nusa Dua is unorganized and dirty. But now Nusa Dua beach is the cleanest beach in Bali, because the hotel and ITDC jointly maintain its cleanliness for the benefit of investors, government and local community. In addition, the beach environment can also be more productive because it can be used economically by local community and tourists. To preserve the marine condition of Nusa Dua since 2009, statue of coral reef has been planted out by the Nusa Dua Reef Foundation, which is very active in conserving coral reefs by transplanting them under the sea. Beside as the growth of coral reefs, coral reef statue is also a home for a variety of fish, a new attraction for marine tourism and the promotion of tourist destinations that are concerned with cultural and environmental preservation. If visitors want to enjoy the beauty of underwater, then the submarine or snorkeling facilities, fishing boats are available to be taken to the sea. They can be rented at Mengiat Beach which is located not far from Samuh Beach. The existence of hotels in the Nusa Dua area also have a positive impact on the environment because the hotel and local communities work together to maintain the preservation of the beach especially the handling of garbage that has been managed well in collaboration with the hotel, ITDC, and Desa Adat.

\section{Model of Beach Utilization in Badung Regency}

The Beach Utilization Model in Badung Regency, takes two beach samples with different types of area. Kuta Tourism Area is an area with integrated development type and Nusa Dua area is enclave development (separate) from local community. These two beaches can represent the beaches in Badung Regency, because other beaches have relatively the same characteristics.

BEACH UTILIZATION MODEL AS A TOURIST ATTRACTION AND RITUAL

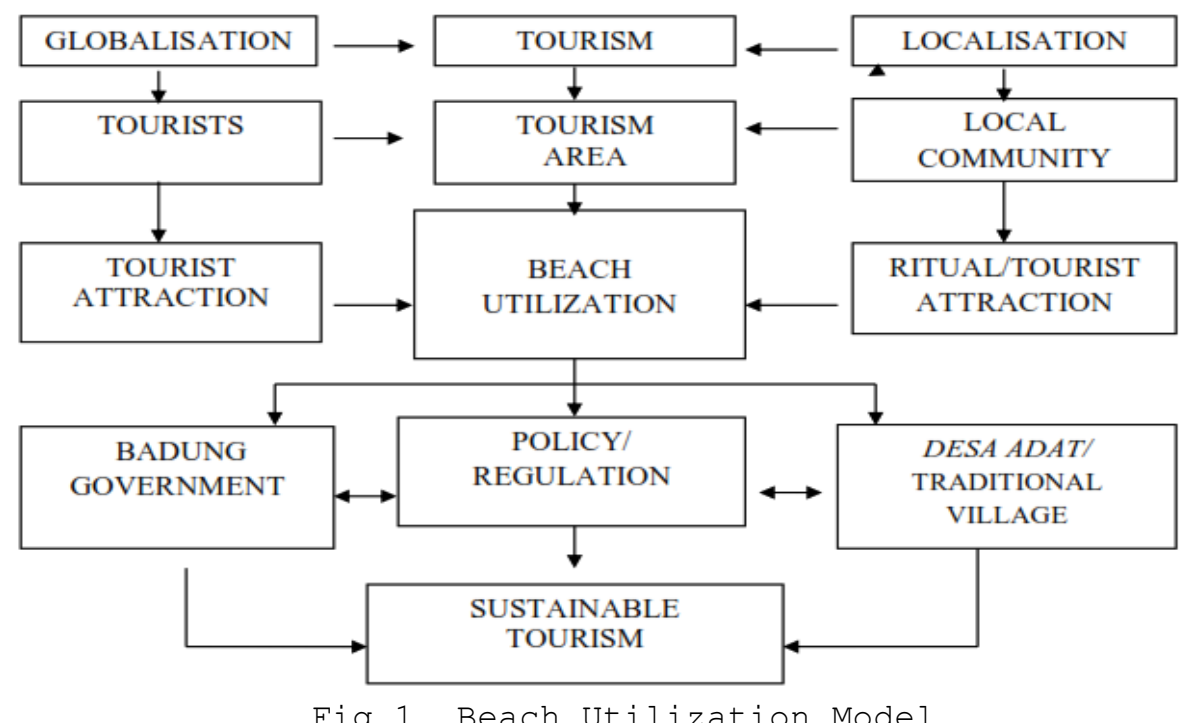




\section{MODEL DESCRIPTION (Fig.1)}

\section{- Globalization}

Globalization affects all aspects of life, including tourism which is a cross-country business and the movement of individuals or groups from, within, and to a destination. Globalization is also influenced by the advancement of information technology and communication, so that one's movement and intellectual development runs rapidly. On the other side, in terms of economy, it greatly facilitates the movement of capital, financial services, exchange of goods and services so that it automatically facilitates the public for transaction. In terms of culture, several countries are increasingly open so as to facilitate countries in the world to interact with each other, establish cooperation in various fields that result in the entry of new cultures, new knowledge, new things from abroad into the country and vice versa. The existence of globalization causes a positive and negative impact on all aspects of life including tourism, therefore there is a need for regulation in a destination that is visited so that harmony can occur towards sustainable tourism. Speaking of sustainable tourism, especially in the zoning of beach utilization in Badung Regency, which involves tourists and local communities, it is necessary to make an agreement so that tourism activities and ritual activities carried out by the local community can run together.

\section{- Localization}

The localization referred to in this model is the opposite of globalization, which is an important component that can also counteract and also offset globalization. In this problem localization is represented by local community who host the Kuta and Nusa Dua tourism areas. In the management of coastal tourism, which involves tourists and local communities, as the host as well as the perpetrators, it is necessary to have awareness, to make tourists comfortable, and to be able to maintain local culture, environment, so that sustainable tourism can be realized.

Both tourism areas Kuta and Nusa Dua, use the beach as a tourist and ritual attraction. It's just that there are different tourist attraction activities offered. But in general there are many similarities such as water sports, massages, long chair rentals, and others. Tourist attraction activities are also carried out by local communities such as bathing, swimming and water sports. For ritual activities are also almost the same, even almost the same as all beaches in Bali in general, namely rituals involving the five yadnya like melasti, ngangkid, nganyut, melukat, nangluk merana, pekelem, odalan, and others.

\section{- $\quad$ Tourism and Tourism Area}

Tourism in this case is seen as a tourism destination or area that involves visitors and hosts community. To make the tourism area remain a sustainable area, it should be paid attention are the satisfaction of tourists and local communities who become a host. Tourist activities in the Kuta and Nusa Dua areas in utilizing the beach, it is necessary to make a model in the form of zoning, in order to create mutual harmony of beach users.

\section{- Tourists and Local Communities}

The use of beaches by domestic and international tourists both on the beaches of Kuta and Nusa Dua, is mostly used for tourism activities such as swimming, bathing, sunbathing, snorkeling, diving, fishing and other watersports. Meanwhile for the local community, utilizing the beach is also for tourism activities such as swimming refresing, and ritual activities such as melasti, nganyud, melukat, ngangkid, mesuci, mulang pekelem/mecaru. nangluk merana, and others.

\section{- $\quad$ Badung Government and Desa Adat}

During this time the use of the coast, especially concerning the use of the beach as a tourist attraction and ritual, has not yet been regulated. So that there are still frequent disruptions such as when local people perform rituals in a dirty manner, suddenly there are tourists who walk with makeshift clothing. In this case, tourists cannot be blamed, because there is no information they have received regarding the prohibition or regulation regarding the ritual activity.

\section{CONCLUSION}

Based on the three problems described above, it can be concluded that the form of beach utilization in Badung Regency which takes two beach samples of Kuta (integrated development) and Nusa Dua (inclave development) is generally the same. It's just that the type of activity as a tourist attraction is different, because the business units are different according to the character of the beach with different waves. The impact of utilization from the economic, social /cultura, 1 and environmental aspects is also the same, both the beaches of Kuta and Nusa Dua which have different developments, but provide the same economic benefits to local communities. In terms of environment, both beaches receive the same attention from both Desa Adat and the government, but for Nusa Dua it is better in management because there is an ITDC, an area manager who is very concerned with the environment in the Nusa Dua area. The utilization model must be realized immediately to avoid problems that occur especially ritual activities carried out by local communities. Beach utilization zoning needs to be established for tourism sustainability in each tourist area. 


\section{ACKNOWLEDGMENTS}

The author expresses his deep gratitude to the Director and Head of P3M Politeknik Negeri Bali, for the research funds provided through the fund of DIPA No: SPDIPA.042.01.2.401006 / 2018. Thanks also to all those who have helped the completion of this study, especially the informants who have given and provided data and information.

\section{REFERENCES}

[1] Murni, N. S., Kanca, I. N., \& Antara, D. M. S. (2018, January). Local cultural conservation to support sustainable tourism in Kuta tourist area. In Journal of Physics: Conference Series(Vol. 953, No. 1, p. 012085). IOP Publishing.

[2] Mowforth, M \& Munt, I. 1998. Tourism And Sustainability, New tourism in the Third World . London: Routledge

[3] Mathieson dan Wall.1986.Tourism: Economic, Phisical and Social Impacts. London: Longman

[4] Kreag, Glenn. 2001. The Impact of Tourism. Minnesota : Sea Grant

[5] Murni, N.G.N., Astawa, I.P. and Budarma, I.K., 2017. Marginalization of Local Community in Tourism Area of Nusa Dua Bali. Advanced Science Letters, 23(12), pp.12211-12214

[6] Murni, N.G., Kumbara, A.A., Sirtha, I.N. and Mudana, I.G., 2014. Global-Local Environment Certification At Five Star Hotels In Tourism Area Of Nusa Dua. Bali E-Journal of Cultural Studies, 7.
[7] Zaei, M.E. 2013 The Impacts of Tourism Industryon Host Community. (European Journal of Tourism Hospitality and Research Vol.1,No.2, pp.12-21, September2013)

[8] Biggs, D., Hicks, C.C., Cinner, J.E. and Hall, C.M., 2015. Marine tourism in the face of global change: The resilience of enterprises to crises in Thailand and Australia. Ocean \& coastal management, 105, pp.65-74.

[9] Perlas, Nicanor. 2000. Shaving Globalization Civil Society, Cultural Power and Three Folding, New York : CADI and Global Network for Social Threefolding

[10] Satumanatpan, S., Moore, P., Lentisco, A. and Kirkman, H., 2017.An assessment of governance of marine and coastal resources on Koh Tao, Thailand. Ocean \& Coastal Management, 148, pp.143-157.

[11]Enemuo,O.B\&OduntanO. C. 2012Sociallmpact Of TourismDevelopment On Host Communities Of Osun Oshogbo Sacred Grove (IOSR Journal of Humanities and Social Science (JHSS)ISSN: 2279-0837, ISBN: 2279-0845. Volume 2, Issue 6 (SepOct. 2012), PP 30-35www.iosrjournals.org

[12] Lincoln Y. S and Norman K Denzin. 2003.Turning Points in Qualitative Research: Tying Knots in theHandkerchief. London: AltaMira Press

[13]Miles, M. B. \& Huberman, A. M. 2009. Analisis Data Kualitatif. (Terj.) Tjetjep Rohendi Rohidi. Jakarta: Universitas Indonesia Press.

[14] Astawa, I.K., Suardani, A.A.P. and Harmini, A.A.A.N., 2018, January. Explorative study on management model of tourism business zone at Kuta, Bali. In Journal of Physics: Conference Series (Vol. 953, No. 1, p. 012074). IOP Publishing. 